\title{
The Effectiveness of Brain-based Learning with using Computerized Applications on the Multiple Intelligences of Children Living under Stressful Conditions in Gaza
}

\author{
Hatem Abu Zaydeh \\ Almustaqbal Research Center \\ Gaza Strip - Palestine
}

\author{
Ibrahim Hamed Al Astal \\ Faculty of Education \\ Islamic University - Gaza
}

\begin{abstract}
This study aims to determine the effectiveness of brain-based learning strategies profile on the multiple intelligences of children living under stressful conditions in Gaza. A case control study was conducted with a purposive sample comprising 45 children (ages 12 to 15 years) in the experimental group and 48 children (ages 12 to 15 years) in the control group. The subjects in two groups were assessed for multiple intelligences before and after brain-based learning strategies profile intervention. No significant differences were found between the experimental and control groups in the pretest results, whereas the posttest results indicated significant differences in all domains excepted musical and intrapersonal intelligences. Brain-based learning strategies are effective and useful for linguistic, mathematical, spatial, kinesthetic, interpersonal and naturalist intelligences.
\end{abstract}

\section{General Terms}

Brain-based learning, Computerized programs, Multiple intelligences

\section{Keywords:}

Brain-based learning strategies, Multiple intelligences, Stress

\section{INTRODUCTION}

Brain-based learning strategies are areas in modern education that provide an opportunity for greater understanding of the learning through the brain to improve learning. Numerous recent studies revealed that the brain has various components and processes, such as electrical activity, structure, metabolism reaction, and neuronal development. Nevertheless, educational sciences have been increasingly oriented toward the study of learning processes and learning outcomes. Education sciences are focused on understanding, cognition, memory, perception, and attention depending on the biology and physiology of the brain.

Jensen defined brain-based learning as "learning in accordance with the way the brain is naturally designed to learn"[1]. Hart described the brain as the organ of learning, and advocated learning more about the brain to design effective learning environments [2]. Brain-based learning is an instruction, which considers how the brain obtains, processes, and interprets information, as well as connects, stores, and recalls the messages [3].

Brain-based learning is dependent on the biological principles of neuroplasticity, which is the ability to strengthen neural occupied territories from the north and east, and covers $360 \mathrm{~km}^{2}$. Gaza Strip has the highest population density in the world at 6,018 people per $\mathrm{km}^{2}$. The majority of the workforce experience connections at synapses and to establish new connections depending on experience, environment, and lifestyle [4] [5]. The connections between brain cells are not only highly changeable, but can also change in a fraction of a second [6]. In the brain, plasticity is the basis of the ability to form new memories and learning. Thus, learning occurs according to the alterations and changes in synaptic connection [7] [8] . Brain-based learning strategies may include multimedia programs in which children can learn by texts supported by movies, images, colored material, animation, and music. The program also includes collaborative learning, rich environments, changeable classroom, physical movement, safe places, and natural environments.

Given the prevailing violence, military actions, and lack of basic necessities in life, children in conflict areas live in tough conditions. Children in the Gaza Strip have been exposed to traumatic events and stressful conditions, such as hearing bombing, witnessing murders, or follow up traumatic events through media and peers [9]. Consequently, these children suffer from a wide range of psychological and emotional problems, such as anxiety, depression, irritability, frustration, anger, worrying, uncertainty, and signs of post-traumatic stress disorders [9] Exposure to chronic stress is associated with cognitive deficits in several domains, such as working memory, declarative memory, attention, and executive functions [10]. Chronic stress causes the inability to concentrate and narrows the attention scope of an individual, which causes difficulty in scanning the full range of possible solutions to complex problems [5].

Several studies have documented the negative impact of stress and traumatic events on cognitive abilities in children, including their multiple intelligences [11]. Most efforts were focused on psychological, emotional, and social manners to help these stressed out children. Nevertheless, few studies have investigated the effectiveness of brain-based learning strategies on the neurocognitive profile of children living under stress, such as multiple intelligences, and which brain-based strategies could be suitable and beneficial for these children living under constant stress.

\section{METHODS}

\subsection{Participants and population}

Gaza Strip is a part of Palestine, which was occupied by Israeli troops in 1948. The strip is a very narrow extended linear area on the coast, and bordered by Egypt on the southwest and by the 
unemployment and very low monthly income due to the circumstances of occupation and overcrowding. Moreover, poverty and deprivation are prevalent in every village and city in the strip [12].

Interventional study was conducted with a purposive sample of 48 children from sixth to ninth grade ( $\mathrm{n}=48,26$ boys, 22 girls) as experimental group and 46 children ( $n=46,24$ boys, 22 girls) as control group. Pretests were performed before the brain-based learning strategies intervention. Posttests were also administered to both the experimental and control groups.

Various brain-based learning strategies were applied during the interventions. Several activities were undertaken outside the classroom, such as green places, natural environments, and seashore. In the classroom, children were divided into small groups, and they learned cooperatively with instructions from the teacher. A number of courses of the sixth to ninth grade curriculum were programmed using suitable software, such as Photoshop, Flash, PowerPoint, and Visual Basic language. The courses were presented as multimedia that consistently combined text, pictures, music, and animation. Computerized learning programs especially in science curriculum were presented in two ways. The learning programs were presented using the LCD screen for all the children in the classroom and in the computer laboratory individually. The environments in the classroom were changed frequently. Posters, images, colors, and lights were provided in line with the lesson. Subjects were allowed to move around the classroom and participate in arranging the instructional materials.

\subsection{Materials}

The validated Arabic version of multiple intelligence test, which was translated into Arabic by Nofal [13], was used. The test comprises eight different areas, namely, linguistic, musical, logical-mathematical, spatial, body-kinesthetic intrapersonal, interpersonal, and naturalist. The score is $(0-10)$ for each domain. The test was administered for approximately $15 \mathrm{~min}$. Mentioning the language level and the ability of children to understand the test is very important.

\subsection{Statistical analysis}

SPSS ver. 15 was used for data entry and analysis (CSC). The means of each domain were calculated separately. Independent ttest was used to compare the means in gender variable, whereas one-way ANOVA test was used to compare the means in income and resident variables.

\section{RESULTS}

\subsection{Sociodemographic characteristics of the study population}

Forty-eight respondents comprising 26 males (54.2\%) and 22 females $(45.8 \%)$ were invited to participate. The ages ranged from 12 to 13 years with mean age of 14.52 years $(S D=0.504)$. Among the respondents, $52.1 \%$ were citizens and $47.9 \%$ were refugees. As for the average family monthly income, $83.3 \%$ earned from equal to or less than US\$250 to US\$500 (see Table 1).

\subsection{Significant differences between experimental and control} groups in multiple intelligences pre-test (Table 2) (Figure 1)

To ensure the equivalence between the experimental and control groups in the multiple intelligence test, t-test was performed. No significant differences in eight intelligences were found ( $p$ values $>0.05)$.
Table 1. Sociodemographic characteristics of the study sample $(n=45)$

\begin{tabular}{|c|c|c|}
\hline & $\begin{array}{c}\text { Frequency } \\
(\mathbf{N})\end{array}$ & Percent (\%) \\
\hline \multicolumn{3}{|l|}{ 1.Sex } \\
\hline Male & 26 & 54.2 \\
\hline Female & 22 & 45.8 \\
\hline Missing value & 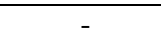 & - \\
\hline Total & 48 & 100 \\
\hline \multicolumn{3}{|c|}{ 2. Age $(14-15)$ Mean $=14.52(S D=0.504)$} \\
\hline \multicolumn{3}{|l|}{ 4. Citizenship } \\
\hline Refugee & 23 & 47.9 \\
\hline Citizen & 25 & 52.1 \\
\hline \multicolumn{3}{|l|}{ 5.Family monthly income } \\
\hline More than 2000 (500 USD & 8 & 16.70 \\
\hline $1000-2000(250-500$ USD & 11 & 22.90 \\
\hline $5000-1000(125-250$ USD & 14 & 29.20 \\
\hline Less than $500(125$ USD $)$ & 15 & 31.2 \\
\hline Total & 48 & 100 \\
\hline
\end{tabular}

Table 2. Significant differences between the experimental and control groups in the multiple intelligence pre-test

\begin{tabular}{|c|c|c|c|c|c|c|}
\hline $\begin{array}{l}\text { Multiple } \\
\text { Intelligences }\end{array}$ & Group & $\mathrm{n}$ & Mean & SD & $\begin{array}{c}p \\
\text { value } \\
\end{array}$ & $\mathrm{t}$ \\
\hline \multirow[t]{2}{*}{ Linguistic } & $\begin{array}{l}\text { Experimental } \\
\text { Group }\end{array}$ & 44 & 7.15 & 1.78 & \multirow[t]{2}{*}{0.56} & \multirow[t]{2}{*}{0.58} \\
\hline & $\begin{array}{l}\text { Control } \\
\text { Group }\end{array}$ & 44 & 6.90 & 2.07 & & \\
\hline \multirow[t]{2}{*}{ Mathematical } & $\begin{array}{l}\text { Experimental } \\
\text { Group }\end{array}$ & 44 & 7.13 & 1.74 & \multirow[t]{2}{*}{0.10} & \multirow[t]{2}{*}{1.66} \\
\hline & $\begin{array}{l}\text { Control } \\
\text { Group }\end{array}$ & 44 & 6.43 & 2.20 & & \\
\hline \multirow[t]{2}{*}{ Spatial } & $\begin{array}{l}\text { Experimental } \\
\text { Group }\end{array}$ & 44 & 7.52 & 1.64 & \multirow[t]{2}{*}{0.56} & \multirow[t]{2}{*}{0.58} \\
\hline & $\begin{array}{l}\text { Control } \\
\text { Group }\end{array}$ & 44 & 7.31 & 1.65 & & \\
\hline \multirow[t]{2}{*}{ Musical } & $\begin{array}{l}\text { Experimental } \\
\text { Group }\end{array}$ & 44 & 6.13 & 2.10 & \multirow[t]{2}{*}{0.18} & \multirow[t]{2}{*}{1.34} \\
\hline & $\begin{array}{l}\text { Control } \\
\text { Group }\end{array}$ & 44 & 6.77 & 2.20 & & \\
\hline \multirow[t]{2}{*}{ Kinesthetic } & $\begin{array}{l}\text { Experimental } \\
\text { Group }\end{array}$ & 44 & 6.75 & 1.76 & \multirow[t]{2}{*}{0.26} & \multirow[t]{2}{*}{1.11} \\
\hline & $\begin{array}{l}\text { Control } \\
\text { Group }\end{array}$ & 44 & 6.26 & 2.26 & & \\
\hline \multirow[t]{2}{*}{ Interpersonal } & $\begin{array}{l}\text { Experimental } \\
\text { Group }\end{array}$ & 44 & 7.47 & 1.51 & \multirow[t]{2}{*}{0.08} & \multirow[t]{2}{*}{1.73} \\
\hline & $\begin{array}{l}\text { Control } \\
\text { Group }\end{array}$ & 44 & 6.77 & 2.20 & & \\
\hline \multirow[t]{2}{*}{ Intrapersonal } & $\begin{array}{l}\text { Experimental } \\
\text { Group }\end{array}$ & 44 & 6.72 & 1.58 & \multirow[t]{2}{*}{0.45} & \multirow[t]{2}{*}{0.75} \\
\hline & $\begin{array}{l}\text { Control } \\
\text { Group }\end{array}$ & 44 & 6.40 & 2.29 & & \\
\hline \multirow[t]{2}{*}{ Naturalist } & $\begin{array}{l}\text { Experimental } \\
\text { Group }\end{array}$ & 44 & 6.50 & 1.93 & \multirow[t]{2}{*}{0.32} & \multirow[t]{2}{*}{0.98} \\
\hline & $\begin{array}{l}\text { Control } \\
\text { Group }\end{array}$ & 44 & 6.06 & 2.20 & & \\
\hline
\end{tabular}


3.3 Significant differences in multiple intelligence post-test (Table 3) (Figure 2)

T-test was used to determine the differences in the eight intelligences in the posttest. The results indicate significant differences in intelligences, namely, linguistic $(p<\mathbf{0 . 0 0 1})$, mathematical $(p<\mathbf{0 . 0 0 1})$, spatial $(p=\mathbf{0 . 0 1})$, kinesthetic $(p=$ 0.001), interpersonal $(p=0.001)$, and naturalist $(p<\mathbf{0 . 0 0 1})$. No significant differences were found in the musical, $(p=0.69)$ and intrapersonal $(p=0.135)$ intelligences.

Table 3. The $p$ values of the experimental and control groups in multiple intelligence post-test

\begin{tabular}{|c|c|c|c|c|c|c|}
\hline $\begin{array}{l}\text { Multiple } \\
\text { Intelligences }\end{array}$ & Group & $\mathbf{n}$ & Mean & SD & $\begin{array}{l}p \\
\text { value }\end{array}$ & $\mathbf{t}$ \\
\hline \multirow[t]{3}{*}{ Ligustic } & Experimental & 45 & 8.01 & 1.43 & $<0.001$ & 4.63 \\
\hline & Group & & & & & \\
\hline & Control Group & 43 & 6.13 & 2.28 & & \\
\hline \multirow[t]{3}{*}{ Mathematical } & Experimental & 45 & 7.889 & 1.78 & $<0.001$ & 3.99 \\
\hline & Group & & & & & \\
\hline & Control Group & 43 & 6.16 & 2.15 & & \\
\hline \multirow[t]{3}{*}{ Spatial } & Experimental & 45 & 7.97 & 1.52 & 0.01 & 2.52 \\
\hline & Group & & & & & \\
\hline & Control Group & 43 & 7.04 & 1.91 & & \\
\hline \multirow[t]{3}{*}{ Musical } & Experimental & 45 & 6.33 & 1.77 & 0.69 & - \\
\hline & Group & & & & & 0.38 \\
\hline & Control Group & 43 & 6.51 & 2.39 & & \\
\hline \multirow[t]{3}{*}{ kinesthetic } & Experimental & 45 & 7.35 & 1.58 & 0.001 & 3.36 \\
\hline & Group & & & & & \\
\hline & Control Group & 43 & 5.92 & 2.10 & & \\
\hline \multirow[t]{3}{*}{ Interpersonal } & Experimental & 45 & 7.81 & 1.37 & 0.001 & 3.36 \\
\hline & Group & & & & & \\
\hline & Control Group & 43 & 6.46 & 2.29 & & \\
\hline \multirow[t]{3}{*}{ Intrapersonal } & Experimental & 45 & 686 & 1.80 & 0.135 & 1.50 \\
\hline & Group & & & & & \\
\hline & Control Group & 43 & 6.20 & 2.26 & & \\
\hline \multirow[t]{3}{*}{ Naturalist } & Experimental & 45 & 7.09 & 1.71 & $<0.001$ & 4.80 \\
\hline & Group & & & & & \\
\hline & Control Group & 43 & 5.23 & 1.91 & & \\
\hline
\end{tabular}

3.4 Significant differences between male and female in the multiple intelligence test (Table 4)

To define the effectiveness of brain strategies based on the neurocognitive profile for children, male and female, the ManWhitney test for two independent samples that are not normally distributed or each group less than 30 subjects, was used to determine the significant differences in the eight intelligences. The results indicate no significant differences in all domains of intelligences ( $p$ values $>0.05$ ).
Table 4. Male and female $p$ values of the experimental group in the multiple intelligence test

\begin{tabular}{|c|c|c|c|c|c|c|}
\hline $\begin{array}{l}\text { Multiple } \\
\text { Intelligences }\end{array}$ & Group & $\mathrm{n}$ & $\begin{array}{l}\text { Mean } \\
\text { Rank }\end{array}$ & $\begin{array}{l}\text { Sum of } \\
\text { Ranks }\end{array}$ & $\begin{array}{l}p \\
\text { value }\end{array}$ & $\mathrm{Z}$ \\
\hline \multirow[t]{2}{*}{ Linguistic } & Male & 23 & 21.67 & 338.00 & 0.46 & \multirow{2}{*}{0.64} \\
\hline & Female & 22 & 23.40 & 403.00 & & \\
\hline \multirow[t]{2}{*}{ Mathematical } & Male & 23 & 23.67 & 361.50 & 0.51 & \multirow{2}{*}{0.64} \\
\hline & Female & 22 & 21.21 & 379.50 & & \\
\hline \multirow[t]{2}{*}{ Spatial } & Male & 23 & 20.57 & 321.50 & 0.28 & \multirow{2}{*}{1.06} \\
\hline & Female & 22 & 24.62 & 419.50 & & \\
\hline \multirow[t]{2}{*}{ Musical } & Male & 23 & 20.39 & 320.00 & 0.24 & \multirow{2}{*}{1.86} \\
\hline & Female & 22 & 24.81 & 421.00 & & \\
\hline \multirow[t]{2}{*}{ kinesthetic } & Male & 23 & 25.87 & 390.50 & 0.06 & \multirow[t]{2}{*}{1.86} \\
\hline & Female & 22 & 18.81 & 350.50 & & \\
\hline \multirow[t]{2}{*}{ Interpersonal } & Male & 23 & 21.00 & 356.00 & 0.40 & \multirow[t]{2}{*}{0.83} \\
\hline & Female & 22 & 24.41 & 385.00 & & \\
\hline \multirow[t]{2}{*}{ Intrapersonal } & Male & 23 & 25.26 & 366.50 & 0.12 & \multirow[t]{2}{*}{1.51} \\
\hline & Female & 22 & 19.48 & 374.50 & & \\
\hline \multirow[t]{2}{*}{ Naturalist } & Male & 23 & 24.07 & 372.50 & 0.39 & \multirow[t]{2}{*}{0.85} \\
\hline & Female & 22 & 20.79 & 368.50 & & \\
\hline
\end{tabular}

3.5 Significant differences between citizens and refugees in the multiple intelligence test (Table 5)

To define the effectiveness of brain strategies based on the neurocognitive profile for citizens and refugee children in the Gaza Strip, suitable tests were performed, while the histogram of two groups were not normally distributed. The Man-Whitney test for two independent samples was performed to determine the significant differences between citizens and refugees in eight intelligences. No significant differences in all domains of intelligences were found ( $p$ values $>0.05$ ).

Table 5. Citizens and refugees $p$ values of the experimental group in the multiple intelligence test

\begin{tabular}{|c|c|c|c|c|c|}
\hline $\begin{array}{l}\text { Multiple } \\
\text { Intelligences }\end{array}$ & Group & $\mathbf{n}$ & $\begin{array}{l}\text { Mean } \\
\text { Rank }\end{array}$ & $\begin{array}{c}p \\
\text { value }\end{array}$ & $\mathbf{Z}$ \\
\hline \multirow[t]{2}{*}{ Iinguistic } & Citizen & 24 & 19.60 & \multirow[t]{2}{*}{0.09} & \multirow[t]{2}{*}{1.69} \\
\hline & Refugee & 21 & 25.89 & & \\
\hline \multirow[t]{2}{*}{ Mathematical } & Citizen & 24 & 25.08 & \multirow[t]{2}{*}{0.13} & \multirow[t]{2}{*}{1.49} \\
\hline & Refugee & 21 & 19.40 & & \\
\hline \multirow[t]{2}{*}{ Spatial } & Citizen & 24 & 20.69 & \multirow[t]{2}{*}{0.37} & \multirow[t]{2}{*}{0.89} \\
\hline & Refugee & 21 & 24.35 & & \\
\hline \multirow[t]{2}{*}{ Musical } & Citizen & 24 & 21.83 & \multirow[t]{2}{*}{0.70} & \multirow[t]{2}{*}{0.38} \\
\hline & Refugee & 21 & 23.30 & & \\
\hline \multirow[t]{2}{*}{ Kinesthetic } & Citizen & 24 & 22.04 & \multirow[t]{2}{*}{0.79} & \multirow[t]{2}{*}{0.26} \\
\hline & Refugee & 21 & 23.05 & & \\
\hline \multirow[t]{2}{*}{ Interpersonal } & Citizen & 24 & 18.69 & \multirow[t]{2}{*}{0.07} & \multirow[t]{2}{*}{2.21} \\
\hline & Refugee & 21 & 27.08 & & \\
\hline \multirow[t]{2}{*}{ Intrapersonal } & Citizen & 24 & 19.77 & \multirow[t]{2}{*}{0.11} & \multirow[t]{2}{*}{1.57} \\
\hline & Refugee & 21 & 25.78 & & \\
\hline \multirow[t]{2}{*}{ Naturalist } & Citizen & 24 & 23.58 & \multirow[t]{2}{*}{0.53} & \multirow[t]{2}{*}{0.62} \\
\hline & Refugee & 21 & 21.20 & & \\
\hline
\end{tabular}




\section{Multiple Intelligences Pret-test}

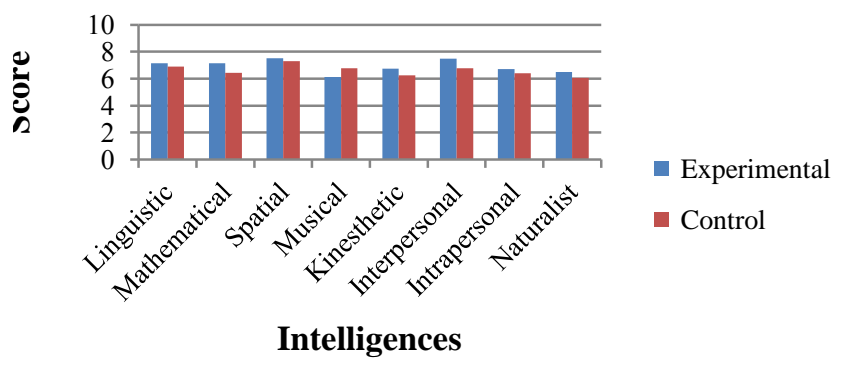

Figure 1: Significant differences between experimental and control groups in multiple intelligences pre-test

\section{Multiple Intelligences Post-test}

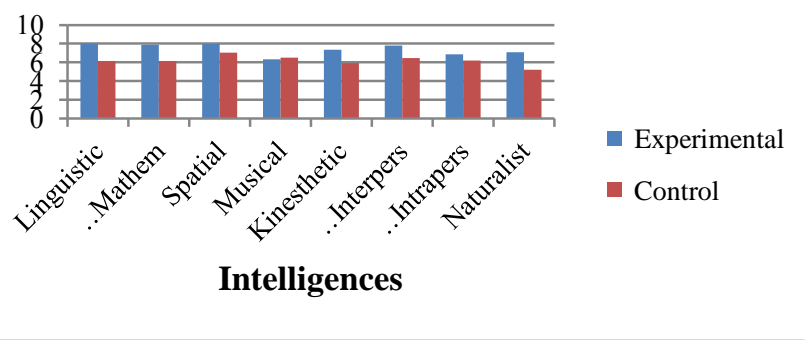

Figure 2: Significant differences between experimental and control groups in multiple intelligences Pose-test

\section{DISCUSSION}

This study followed the pretest, posttest control group design to determine the effectiveness of brain-based learning strategies on the multiple intelligences of children living under stressful conditions in Gaza. Significant differences in the post test results were found in all domains excepted musical and intrapersonal intelligences. These findings may be explained by the brain-based learning strategies that were applied.

The intervention increases the neural connections, synapses, and dendritic branching in the brain with stimulation [14].

Enriched environment, which is dependent on the multiplication of various sensory stimuli surrounding children, is based on the principle that humans have various abilities for learning. Visual, auditory, olfactory, touch, taste, and other senses can improve learning because the input and understanding are considerably increased as more senses are used, consequently producing good learning outcomes. A rich learning environment can heighten the sensation to learn and provide environmental stimulation. The routes to learning are through key sensors, such as the ears, eyes, nose, nerves, and the sixth sense or intuitive insight [15].

Multimedia programs are also effective strategies, which could explain their positive effects on intelligence. Multimedia refers to any computer-mediated software or interactive application that integrates text, color, graphical images, animation, audio sound, and full motion video in a single application. Multimedia presents words and pictures that are intended to promote learning.
Learning with multimedia programs encourages a studentcentered learning mode, in which students play an active part in their learning process and become autonomous learners who are actively engaged in constructing new meaning within the context of their current knowledge, experiences, and social environments [16]. Learning with multimedia programs induces virtual learning, which has created an entirely new learning environment that enables learners to take charge of their own educational experiences. Petre (2001) argued that "learning was higher when information was presented via computer-based multimedia systems than traditional classroom lectures [17]."

Collaborative learning is a popular instructional strategy that focuses on cooperation among students and between teachers and children. Children gain a deeper understanding of the event, thereby constructing their own knowledge and solutions to problems. This learning environment encourages students to develop critical thinking skills, problem-solving and team skills, experiential learning, and interdisciplinary knowledge, with technology being integral to their learning [18].

Collaborative brain-based learning activities typically occur in a relaxed and alert environment [19], which enable groups of learners to co-construct more powerful understandings than an individual can construct alone [20] [21] [18]. Humans are social organisms. The individual behaves with others in a different manner if he/she is alone. The brain develops and refines his/her skills and experiences through interaction with others due to the promotion of effective social learning, which encompasses faceto-face interaction, positive interdependence, group and individual accountability, small-group decision-making skills, and meta-processing skills. The students were able to develop interpersonal skills and participate in brainstorming activities while making decisions concerning their project. Through the intervention, a wide range of stimuli were used in the classroom with frequent changes to the traditional environment in the classroom. Posters, pictures, colored images especially in the science subject, multi-colored shapes and sizes of cards, models, and samples with various sizes were also used. Children went out at least once every month to the natural environment, which has trees, gardens, and seashore. Abdulkader et al. (2009) studied the effect of the program based on the multiple intelligences in reading skills in 5-th years primary learning disabled students [22]. The results indicated that the program employed to improve reading skills was effective. Bas and Beyhan (2010) reported that the multiple intelligence approach to activities was positively effective in improving the attitudes and achievements of students [23]. Morever, the students who were educated with multiple intelligence supported project-based learning method were more successful and had higher motivation levels than the students in the control group [23].

In the musical and intrapersonal intelligences, the lack of significant differences has various reasons. In musical intelliegence, the prevalent socio-cultural aspects in the Gaza Strip may explain this finding. In addition, music was rarely used with brain-based strategies because music was unfavorable to apply especially for children and shortage of resources due to the seige is another reason. The absence of a significant difference in intrapersonal intelligence may be explained by the insufficient time allocated for the intervention. The desired change in intelligence such as intrapersonal intelligence may require years with various procedures and learning strategies. Moreover, no statistically significant differences were found in the variables of gender and citizenship. These findings are not surprising because of the homogeneity among the people in Gaza, especially among children. Gaza is a narrow coastal strip, and the area is approximately $360 \mathrm{~km}^{2}$ with no breaks or insulation between the cities and camps in the Gaza Strip. Rather than having distinctive 
social relations and internal cohesion of the community, this area creates consistency and harmony among members of the society, and thus harmonizes a pattern of habits, behaviors, and traditions among children.

\section{CONCLUSION}

The findings in this study indicated that brain-based learning strategies could improve multiple intelligences according to Gardner's theory, which result in numerous practical applications in the classrooms. Developing these educational strategies and employing them to serve the educational process, especially in areas where children suffer from stress that affects their performance, are necessary.

This study is insufficient in detecting the impact of learning strategies on multiple intelligences. Nevertheless, conducting more extensive studies to individually address brain-based strategies is essential. Additionally, the trial period should be more than six months.

\section{REFERENCES}

[1] Harris, J. 2004. Personal Learning Theory Marshall University, West Virginia, pp. 112-125.

[2] Johnson, L. \& Lamb, A. 2007. Brain-based (compatible) learning. [Online] Available from:www.eduscapes.com/tap/topic70.htm [Accessed 21-32012].

[3] Duman, B. 2006. In: $9^{\text {th }}$ International Conference on Engineering Education.Turkey, pp. 17-25.

[4] Connell, J. D. 2005. Brain-based strategies to reach every learner. $5^{\text {th }}$ Edition. USA: Scholastic Inc., pp. 17-32, 77-95.

[5] Servan-Schreiber, D., Le Lin, B. \& Birmaher, B. (1998) Prevalence of posttraumatic stress disorder and major depressive disorder in Tibetan refugee children. Journal of the American Academy of Child \& Adolescent Psychiatry, 37(8), 874-879.

[6] Stettler, D. D., Yamahachi, H., Li, W., Denk, W., \& Gilbert, C. D. 2006. Axon and synaptic boutons are highly dynamic in adult visual cortex, Neuron, 49, 877-887.

[7] Gazzaniga, M. \& Heatherton, T. 2003. Psychological science: mind, brain, and behavior. New York: W. W. Norton and Company, Inc., pp. 125-156, 172-182, 186-193.

[8] Cercone, K. 2006. Brain-based learning. In: Sorensen, E. K. \& Murchú, M. O. Enhancing Learning Through Technology. USA: Information Science Pub., pp. 292-323.

[9] Altawil, M., Harrold, D. \& Samara, M. 2008. Children of war in Palestine. The International Journal of Evacuee and War Child Studies, 1(5), 5-13.

[10] Morgan, C.A., Doran, A., Steffi, G., Hazlett, G. \& Southwick, S.M. 2006. Stress-induced deficits in working memory and visuo-constructive abilities in Special Operations soldiers. Biol.Psychiatry, 60:722-729.
[11] Almeida, D. M. 2005. Resilience and vulnerability to daily stressors assessed via diary methods. Current Directions in Psychological Science, 14(2), 64-68.

[12] Thabet, A. A., El Sarraj, E. \& Vostanis, P. 2009. The relationship between siege of Gaza Strip, anger, and psychological symptoms. [Online] Available from:http://www.gcmhp.net/ [Accessed 21-3-2012].

[13] Nofal, M. B. 2010. Multiple intelligences in the classroom. 2nd Edition. Amman: Dar Elmaseer, pp. 311-325.

[14] Poirazi, P. \& Mel, B. W. 2001. Impact of active dendrites and structural plasticity on the memory capacity of neural tissue. Neuron, 29(3), 779-796.

[15] Beard, C. \& Wilson, J. P. 2002. The power of experiential learning. London: Colin Beard and John P Wilson, pp. 90$115,192-221$.

[16] Isa, A. 2010. Multimedia: a constructivist approach to learning. Continental J. Information Technology, 4, 9-14.

[17] Petre, D. 2001. The effect of multimedia learning environment of students' performance. The Journal of Instructional Technology, 2(11), 12-15.

[18] Eggen, P. \& Kauchak, D. 2007. Educational psychology: windows on classrooms. 6th Edition. New Jersy: Pearson Education International, pp. 75-78.

[19] Pool, C. 1997. Maximizing learning: a conversation with Renate Nummela Caine. Educational Leadership, 6(54), 1115.

[20] Donell, A. \& Kelly, J. 1994. Learning from peers: beyond the rhetoric of positive results. Educational Psychlogy Review, 6(4), 321-349.

[21] Keefer, M., Zeits, C. \& Resnick, L. 2000. Judging the quality of peer-led student dialogues. Cognition and Instruction, 18(1), 53-81.

[22] Abdulkader, F., Gundogu, K. \& Eissa, M. A. 2009. The effectiveness of a multiple intelligences-based program on improving certain reading skills in 5th-year primary learning disable students. Electronic Journal of Research in Educational Psychology, 7(3), 673-690.

[23] Bas, G. \& Beyhan, Ö. 2010. Effects of multiple intelligences supported project-based learning on students' achievement levels and attitudes towards English lesson. International Electronic Journal of Elementary Education, 2(3), 365-385. 